\title{
Scientific worldviews as promises of science and problems of philosophy of science*
}

\section{Thomas Mormann}

Department of Logic and Philosophy of Science, University of the Basque Country UPV/EHU, Donostia-San Sebastian, Spain

\section{Correspondence}

Thomas Mormann, Department of Logic and Philosophy of Science, University of the Basque Country UPV/EHU, Avenida de Tolosa 70, 20080 Donostia-San Sebastian, Spain. Email: thomasarnold.mormann@ehu.eus

\section{Funding information}

Spanish Ministry of Economy and Competitiveness (MINECO), Grant/Award number: FF2015-69792-R
The aim of this paper is to show that global scientific promises aka "scientific worldviews" have an interesting history that should be taken into account also for contemporary debates. I argue that the prototypes of many philosophical positions concerning the role of science in society can already be found in the philosophy of science of the 1920s and 1930s. First to be mentioned in this respect is the Scientific World-Conception of the Vienna Circle (The Manifesto) that promised to contribute to the realization of an enlightened, rational, and science-oriented society and culture. The Manifesto was not the only "scientific world-conception" that philosophers and scientists put forward in the 1920s. Also the scientific worldconception of the philosopher and physicist Moritz Schlick, and the Weltanschauung of Sigmund Freud deserve to be mentioned. Additional examples include Carnap's Scientific Humanism and the project of The International Encyclopedia of Unified Science which was related to American pragmatism as well, as is shown by Charles W. Morris and others. Forgotten for a long time, since the beginning of the 21st century, at least some of the Viennese projects are reconsidered in a new wave of "socially engaged philosophy of science."

\section{KEYWORDS}

Charles W. Morris, Moritz Schlick, scientific world views, Sigmund Freud, socially engaged philosophy of science, Vienna Circle

\section{PROMISES OF SCIENCE AS PROBLEMS OF PHILOSOPHY OF SCIENCE}

Promises play an important role not only in ordinary life but also in modern science. Perhaps one may even say that they are essential for science: A science that does not strive for the realization of certain aims, i.e., one that does not make certain promises, will hardly get the necessary societal

\footnotetext{
*This article is part of the Special Issue The Promises of Science. Historical Perspectives with Jaume Navarro as the guest editor.
} 
support for carrying out its research. In this way, promises of some kind or other play an important role in a science, be it the mundane promise that it will help construct new useful technological devices or be it the pseudo-religious general promise that this science will make an essential contribution to find the 'truth that will set us free'.

For the purposes of this paper, it is expedient to distinguish between two different types of scientific promises to be called "local promises" and "global promises," respectively. For instance, the promise that progress in engineering will mean that trains from Madrid to Paris only take 2 or 3 hrs appears to be a rather local promise that would not, if satisfied, change the global structure of society. On the other hand, if genomic science fulfilled the promise that a complete analysis of the human genome will lead to the invention of new drugs and treatments that enlarge the average human life-span to more than 200 years, this would be classified as a global promise that profoundly influences the way of living of mankind as a whole. Distinguishing between local and global promises may be anything but easy. Many scientific promises, which first looked quite local, later showed an immense global impact changing even into global threats caused by science. This is an interesting problem but not one that will be treated in this paper. In this contribution l'd like to deal with scientific promises that may be considered as the most global promises of all, namely, those that can be characterized as global Scientific Worldviews. As Sigmund Freud put it, a global scientific worldview in this sense promised a.

...unified solution of all the problems of our existence in virtue of a comprehensive scientific account of the world, in which no question was left open and in which everything in which we are interested in finds a place. The possession of such a global scientific worldview, in the German tradition often called Weltanschauung has been one of the ideal wishes of mankind. When one believes in such a vision, one feels secure in life, one knows what one ought to strive after, and how one ought to organise one's emotions and interests to the best purpose. ${ }^{1}$

If science could provide us with a scientific worldview in this sense that would give us a means of organizing our individual lives as well as our society according to scientific, i.e., rational standards. ${ }^{2}$ Global scientific promises aka global scientific worldviews generate philosophical problems concerned with problems of the very nature of science. Scientific Worldviews entail that science no longer can be identified with "innocent" knowledge that describes "nature as it is." Rather, global scientific worldviews indicate that it is of crucial importance to understand philosophically the relation between "objective" scientific knowledge and "subjectively motivated" scientific promises.

Up to now, neither science nor philosophy of science actually have generated a comprehensive scientific Worldview, nor has philosophy of science agreed upon stable and unanimously accepted answers of how to assess the feasibility and scientificity of such global projects. It seems clear that certain "knowledge interests" and "values" of various kinds play an important role here, but it is far from clear what is the precise role of these ingredients in the endeavor of science. At least one can say the following: If promises are essential ingredients of science, this is evidence that science is not only concerned with facts but also with possibilities; in order to consider an assertion as an at least prima facie reasonable promise at all, first one must believe that it can be realized and secondly that it should be realized. These assessments involve valuations of some kind or other.

The problem of valuating possibilities is the more urgent, the larger the space of scientific possibilities is. What we need, then, is a working theory of valuating scientific possibilities. Thereby science is to be considered as a subsystem of society determined by, and, at the same time, determining society. From this perspective, the relations

\footnotetext{
${ }^{1}$ Freud, 1933, p. 195.

${ }^{2}$ It should be noted that according to Freud psychoanalysis could not offer such a comprehensive Weltanschauung. Even more, he firmly believed that no science at all could honestly make such a promise. He did, however, believe that psychoanalysis, as an empirical science among others, could contribute to diminish unnecessary psychological suffering. This may be considered as a promise on a much more modest scale.
} 
between science and society are an integral issue of philosophy of science. This entails that philosophy of science no longer can maintain that its proper goal is to "understand the structure and the meaning of science itself" without taking into account the embedding of science in society. History of philosophy of science shows that up to now philosophers have not yet found a stable and unanimously agreed stance with respect to the task of a philosophical understanding of the role of global scientific promises for science and society.

Actually, the discussion concerning the respectability and feasibility of scientific worldviews (or how ever this , kind of global scientific promises may be called) is actually not new. The issue of scientific promises has an interesting history and this history should be taken into account also for contemporary debates. More precisely, l'd like to argue that the prototypes of many contemporary philosophical positions, which are relevant for contemporary discussions concerning the issue of scientific promises, can already be found in the philosophy of science of the 1920s and 1930s. Hence, in dealing with promises in science it may be philosophically expedient to have a closer look at the history of philosophy of science.

The outline of this paper is as follows: The next section briefly recalls the basic tenets of the Scientific world conception $^{3}$ of the Vienna Circle, usually referred to as the Manifesto of the Vienna Circle. The Manifesto was launched anonymously in 1929. Its authors were the sociologist and economist Otto Neurath, the philosopher and logician Rudolf Carnap, and the mathematician Hans Hahn. Until today the Manifesto may be considered as the most influential example of a global scientific promise, namely, to contribute to the realization of an enlightened, rational, and science-oriented society and culture. Perhaps less known is the fact that the Manifesto in no way was the only "scientific worldview" that philosophers and scientists put forward in Vienna after World War I. There are at least two other interesting examples of global Viennese scientific worldviews. In this paper l'd like to deal with the scientific worldview of the philosopher Moritz Schlick, who was the official head of the Vienna Circle, and with the Weltanschauung of the founder of psychoanalysis Sigmund Freud.

Philosophy of science never was, of course, an exclusively Viennese affair. Since the early 1930s the logical empiricists of the Vienna Circle began to forge links with American pragmatism and other currents of "scientific philosophy" in France and Britain. Particularly important for the issue of scientific Worldviews and their promises was the collaboration of philosophers of the Vienna Circle and some American pragmatists in the project of The International Encyclopedia of Unified Science. One of the aims of the encyclopedistic project was to make scientific knowledge accessible to a general public thereby fostering a general "scientific worldview" for society as a whole. From the side of American pragmatism the main protagonist of the encyclopedistic project was the philosopher and semiotician Charles W. Morris. Indeed, Morris' project was to forge a synthesis between European logical empiricism and American pragmatism. ${ }^{4}$

In the second part of this section we briefly deal with Carnap's Scientific Humanism that he sketched at the end of his philosophical career in his intellectual Autobiography ${ }^{5}$ and that he claimed to be the core of the common scientific Weltanschauung of the members of the Vienna Circle. By the 1950s at the latest the project of the Encyclopedia had faded away and the issue of global scientific promises and scientific worldviews gradually disappeared from the agenda of mainstream philosophy of science. Meanwhile, the tides have changed again. Since the beginning of the 21st century there is a new wave of "socially engaged" philosophy of Science. The paper concludes with some brief remarks on this topic.

\footnotetext{
${ }^{3}$ The Logical empiricists of the Vienna Circle distinguished (at least officially) between "Weltanschauung" (world view) and "(wissenschaftlicher) Weltauffassung" ((scientific) world conception). They insisted that their Manifesto was a (scientific) Weltauffassung in contrast to the many (non-scientific) world views. By hindsight one has to say that drawing a line between what is scientific and what is not is far more difficult than the Logical empiricists were prepared to admit. More than once, even the members of the Vienna Circle could be caught using the (more common) term Weltanschauung when the official linguistic ruling required Weltauffassung. For a detailed discussion of the thorny issue to distinguish between the two concepts, see Romizi, 2012, 2013. In this paper I will always use the more general term "world view" instead of the somewhat artificial term "world conception" except when I deal explicitly with the Vienna Circle's "world conception."

${ }^{4}$ cf. Morris, 1937.

${ }^{5}$ Carnap, 1963.
} 


\section{2 | THE SCIENTIFIC WORLD CONCEPTION OF THE VIENNA CIRCLE}

The natural starting point for outlining the Vienna Circle's philosophy of science and the role that scientific promises played for it is the so-called Manifesto The Scientific World-Conception. The Vienna Circle (1929). For reasons of space we have to concentrate on three of the Circle's main figures, namely, Rudolf Carnap, Otto Neurath, and Moritz Schlick. Even under this restriction it can be shown that the Vienna Circle's philosophy of science was anything but a monolithic school doctrine accepted by all its members. Indeed, these authors have put forward quite different theses concerning scientific promises and their philosophical assessments. ${ }^{6}$

The Manifesto (authored by Neurath, Carnap, and Hahn) is often considered as a rather crude philosophical pamphlet that was not much interested in the more subtle distinctions of academic philosophy. This is a bit unfair. The Manifesto was a "manifesto" i.e., a text that wanted to persuade as many people as possible pointing at some rather complex issues concerning the relation of "science," "life," and "politics." These topics not only mattered for the early 20th century but may be relevant also for the agenda of contemporary discussions.

The "scientific world conception" of the Manifesto was only one among many rival proposals. In order to get a better understanding of the Manifesto itself and its role in the broader context of the time it is expedient to compare it with some other "scientific worldviews" of the time. This will help bring into focus the specific philosophical shortcomings as well as advantages of the Manifesto. Thereby the possible relevance of the issues dealt with in the Manifesto even for contemporary discussions may become evident. ${ }^{7}$ According to the Manifesto's high-sounding closing remarks.

We witness the spirit of the scientific world-conception penetrating in growing measure the forms of personal and public life, in education, upbringing, architecture, and the shaping of economic and social life according to rational principles. The scientific world-conception serves life, and life receives it. ${ }^{8}$

These elucubrations make it quite clear that the Manifesto was not so much a piece of theoretical philosophy but rather an attitude: a set of recommendations, which served (and to a certain extent for some still serve) as guide-lines for doing philosophy of science. Implicitly it entailed a particular set of values. Although the Vienna Circle's philosophers did not support any theory of objective values, they shared, more or less implicitly, certain values, even if they did not provide a justification for them. For instance, they had a high esteem for science, conceptual clarity, and the reliance on empirical evidence.

According to the Manifesto the scientific world conception was characterized by the fact that it

... knows no unsolvable riddle. Clarification of the traditional philosophical problems leads us partly to unmask them as pseudo-problems, and partly to transform them into empirical problems and thereby subject them to the judgment of experimental science. The task of philosophical work lies in this clarification of problems and assertions, not in the propounding of special 'philosophical' pronouncements. The method of this clarification is logical analysis. ${ }^{9}$

The authors of the Manifesto ascribed the merit of having discovered the power of this new instrument (modern logic) for philosophy to Bertrand Russell. According to them, conceiving the new relational logic as the method of

\footnotetext{
${ }^{6}$ Up to now, the most comprehensive presentation of the history and philosophy of the Vienna Circle is FriedrichStadler's bulky volume The Vienna Circle. Studies in the Origins, Development, and Influence of Logical Empiricism where the reader finds a wealth of information on the philosophical, sociological, and historical aspects of the Vienna Circle: Stadler, 1997.

${ }^{7}$ For detailed information about the "production history and early reception of The Scientific World Conception" the reader may consult Thomas Uebel's paper of the same title: Uebel, 2012.

${ }^{8}$ Neurath, 1929, p. 306.

${ }^{9}$ Neurath, 1929, p. 305.
} 
philosophy was to bring about a progress in philosophy of the same kind of magnitude as had been the introduction of mathematics into physics by Galileo. Similar announcements can be found in Carnap's Aufbau. ${ }^{10}$ Perhaps, Carnap may have felt that the claim that according to the Manifesto there were no unsolvable riddles sounded a bit grandiloquent to some readers. In order to avoid this misunderstanding Carnap added the explanation that the elimination of scientific riddles by a scientific world conception did not mean that all the "unsolvable riddles of life" would be dissolved and disappear. For him, the riddles of life were not theoretical questions of science, but practical situations that fell outside the ken of science.

Already in this early stage of the evolution of logical empiricism one finds among Carnap and some other members of the Circle the tendency of strictly separating the theoretical sphere of science and the practical sphere of action. Scientific knowledge was considered as theoretical knowledge, that was only of limited use for practical problems. Later, this tendency was to lead to serious frictions with American pragmatism.

The implicit promise of a logical empiricist scientific Worldview was that science would play an essential and indispensable role in the endeavor of bringing mankind a further step forward on the road to a progressive, more humane society. The internal progress of science was taken as evidence that science would bring about also a societal progress in general. The contribution of philosophy of science in this endeavor was twofold: Internally, philosophy of science helped clarify the assertions of science, making explicit the logic of science, so to speak. Externally, philosophy of science helped science find its place in the global system of society, and, moreover, helped society understand science, its possibilities, and limitations. Summing up, the authors of the Manifesto concluded:

The scientific world-conception is close to the life of the present. ... We witness the spirit of the scientific world-conception penetrating in growing measure the forms of personal and public life, in education, upbringing, architecture, and the shaping of economic and social life according to rational principles. The scientific world-conception serves life and life receives it. ${ }^{11}$

This concluding statement of the Scientific World-conception of the Vienna Circle can be interpreted in many ways, but certainly it cannot be considered as a scientifically justified assertion in the traditional sense.

\section{3 | TWO OTHER VIENNESE WORLDVIEWS: SCHLICK AND FREUD}

The "Scientific World-Conception" of the Manifesto was not the only "world-vision" put forward in the scientific and philosophical circles of Vienna during the 1920s and 1930s. Indeed, at that time, many "Vienna circles" existed, and many of them presented their more or less scientific "Viennese worldviews." ${ }^{12}$ These circles did not live in isolation, and many intellectuals, philosophers, or scientists were members of two or more different circles, sometimes with quite different orientations.

Complementarily, belonging to one circle did not entail that someone subscribed to the circle's official ideology in toto. It goes without saying that in this paper we cannot give an overview of all these intellectual endeavors and their global premises. Instead, l'd like to deal with only two of them which are of special interest for the topic of this paper, namely, the issue of global "scientific" world visions put forward by them. The first example is Moritz Schlick's account of the Vienna Circle that substantially differed from the version that had been put forward in the Manifesto. The second example is Sigmund Freud's circle based on the "new" science of psychoanalysis which had its own scientific promises to change the human condition for the better.

\footnotetext{
${ }^{10}$ Carnap, Aufbau $\$ 183$.

${ }^{11}$ Neurath, 1929, p. 315.

${ }^{12} \mathrm{~A}$ rather comprehensive list of them and their characteristic features may be found in Edward Timms's work Die Wiener Kreise: Timms, 1996. These circles were not isolated groups. Rather, there was a lively exchange of ideas and persons between many of them. This held, in particular, between Freud's circle and the Vienna Circle around Schlick. Contacts between the members of these circles took place even in the emigration (see section 4).
} 
The official leader of the Vienna Circle Moritz Schlick to whom the Manifesto was dedicated, heartily disliked it, particularly for its leftist political bias. Indeed, Schlick's political convictions were opposed to many of those endorsed by the authors of the Manifesto, and he had quite different ideas of how science, philosophy, and society were related. By education Schlick was a physicist and philosopher and had obtained a PhD in physics under Max Planck. In the early decades of the past century he had a close relation with Einstein and served as his philosophical spokesman. Not being content with privately rejecting the Manifesto of Neurath, Carnap, and Hahn, he put forward his own "manifesto" in which he explained his "scientific worldview." As leader of the Vienna Circle he published it as the opening article The Turning Point in Philosophy ${ }^{13}$ in the journal Erkenntnis, the official organ of the Vienna Circle in the 1930s. Schlick agreed with Carnap, Hahn, and Neurath that the natural sciences were the essential ingredient for the formation of a rational worldview. In blatant contrast to them, however, he contended that science had nothing to do with the "practice of life." For him it went without saying that technological progress and applications were essentially irrelevant for the natural sciences. Rather, the aim of science was purely theoretical, namely, the investigation of nature as it is. Consequently, science had nothing to do with the rest of society. This entailed that according to Schlick the scientific worldview made no socially relevant promises at all. Insofar it is located rather far away from most other scientific worldviews to be discussed in this paper. Schlick's account is particularly interesting, since he attempted to determine the role of humanities (Geisteswissenschaften) for a comprehensive scientific worldview. Schlick may be characterized as a partisan of a kind of Pythagorean aestheticism for which the beauty of mathematical physics played a crucial role.

Philosophie und Naturwissenschaften ${ }^{14}$ may be considered as a popular version of the more academic Turning Point. ${ }^{15}$ It is the elaboration of a lecture that Schlick gave in 1929 at the university of Vienna as part of a popular lecture series The Worldview of the Natural Sciences. ${ }^{16}$ Schlick's terminology considerably differs from that used in the Manifesto. He distinguishes between "Weltbild" (world image or scientific image) and "Weltanschauung" (worldview): The natural sciences (and they alone) were said to create an image of reality. The task of philosophy of science was to manufacture from this "scientific image" a "worldview":

The transition of the scientific image of the world to the worldview is done simply by rendering completely clear to oneself the meaning of the scientific image, by realizing what is actually meant by it - quite similarly as viewing a piece of art is opposed to merely looking at it consists in the fact that the specific colors and forms obtain a certain meaning, represent something, tell something to the observer. Expressed differently: The scientific image of the world is not converted to a worldview by adding new thoughts, but by understanding it. ${ }^{17}$

The error of the metaphysicians was, Schlick asserted, that they considered philosophy as a system of knowledge, whereby the worldview would emerge from scientific knowledge by adding to it some new metaphysical assertions. Thereby the scientific truths were embedded into a higher comprehensive system. According to Schlick, the relation between science and philosophy was different, but nevertheless very intimate. He even went so far as to characterize the philosopher's clarification of meaning of the scientific image as the "soul of all research". ${ }^{18}$ For Schlick, the paradigm for this "philosophical science" or "scientific philosophy" was Einstein's work:

Einstein's work, proceeding from an analysis of the meaning of statements about time and space, was actually a philosophical achievement. ... [T] he decisive epoch-making forward steps of science

\footnotetext{
${ }^{13}$ Schlick, 1931.

${ }^{14}$ Schlick, 1934

${ }^{15}$ Schlick, 1930.

${ }^{16}$ In his paper, Schlick uses throughout the terms "Weltbild" and "Weltanschauung" instead of the "officially recommended" "Weltauffassung." Perhaps this may be interpreted as an implicit criticism of the Manifesto.

${ }^{17}$ Schlick, 1934, p. 384.

18 ibid., p. 383.
} 
are always of this character. They signify a clarification of the meaning of the fundamental statements and only those succeed in doing this who are talented for philosophical activity. The great investigator is also always a philosopher. ${ }^{19}$

At a certain point, then, the knowledge of the (mathematized) empirical sciences becomes dependent on philosophy. Philosophy is to become science, and science is to become philosophy in order to achieve its real beauty:

In other words, it is the philosophical activity by which the knowledge of empirical science achieves the beauty of its results. The empirical investigation of nature does not mention philosophy, it bears philosophy in itself. ${ }^{20}$

By its very construction, Schlick's scientific worldview did not make any promises concerning human welfare or something similar. The aim of science was to know what is the case and to understand it. Science did not aim at technical domination of nature. Thus, according to Schlick, the philosophico-scientific worldview is totally unrelated to any mundane social and political considerations.

One question remains still open: where is the place of the humanities in Schlick's account? He explicitly asserted that the intimate relation between philosophy and science and their eventual identity does not hold for the humanities. In contrast to the sciences, philosophy does not contribute anything to the humanities nor viceversa. The humanities always remain close to common sense. There is no domain of nature on the one hand, and another domain of the mind (spirit) on the other. Consequently, the difference between the sciences and humanities was not a difference of objects, but only a difference in the ways of how to investigate the world, namely, a difference in methods. The humanities were based on common sense concepts. As Schlick drastically asserted, history today proceeds in the same way as in the day of Thukydides. If a so called Geisteswissenschaft such as psychology no longer used non-common sensical ("scientific") concepts it changed its character toward an empiricial science. The humanities have to do only with human interests.

The scientific image of the world is produced only by the empirical sciences. ... The humanities do not yield knowledge, they are valuating. Only reason can draw an image of the world. In its highest form the scientific image of the world is mathematical. Looking at the route that mechanics has covered from Archimedes over Galileo to Einstein, one can be only astonished about the immense amount of ingenuity that was necessary to pursue this way, and which is available now in the completed concepts of science. In comparison, the historical disciplines only work with ideas that remain quite close to those of daily life and intuitive nature. Thus one may say that in the basic concepts of the humanities there is much more nature, and in those of the natural science more reason. ${ }^{21}$

The scientist had to be a philosopher in order to understand and to elaborate the basic concepts of his science; and the philosopher achieves his worldview only from starting with the image of empirical science. For Schlick, there was only one serious image of the world, namely, the scientific image. ${ }^{22}$ As is emphasized the scientific image of the world was manufactured by the empirical sciences (and by the empirical sciences alone), philosophers helped understand it. Then one may ask, what was the role of the humanities - if they had any role at all? According to Schlick, their role is not purely theoretical, i.e., directed to pure knowledge (as is the case for the natural sciences) but "experience-oriented" in the following sense:

\footnotetext{
${ }^{19}$ Schlick, 1930, pp. 9-10.

${ }^{20}$ Schlick, 1934, p. 396.

${ }^{21}$ Schlick, 1934, p. 395.

${ }^{22}$ Schlick never came close to considering the issue of the legitimacy of what later has been called the "manifest image" or the "Lebenswelt."
} 
The very last aim of the humanities (Kulturwissenschaften, Geisteswissenschaften) is to offer to contemporary man the possibility of re-experiencing the Erlebnisse of people of a by-gone age, thereby taking part at them, resuscitating the past in his own soul. ... This is the beauty, the power and the irresistible fascination of the Geisteswissenschaften that they deal with human affairs only in service of humanity. ... Thereby they approach the sphere of art and move apart from philosophy. ${ }^{23}$

Schlick rejected any kind of perspectivism according to which the natural sciences only deal with certain aspects of the world and the other sciences with others. For him there was only one kind of knowledge - he considered it as positively misleading to contrast the knowledge of the natural with that of the Geisteswissenschaften. For him, there existed one only worldview, namely, that of the natural sciences, the only task that remained for philosophy was to interpret it. The task of the humanities was to valuate the worldview determined by natural science.

Schlick subscribed to a fundamentally disengaged, esthetically motivated attitude. According to him, the fact that philosophy did not generate a worldview through free and independent speculation, but depended in this respect completely on the result of the experiential sciences, did not affect negatively the greatness of the philosophical worldview, because a worldview that faithfully followed experience was much more colorful, artful, and richer than one that could be invented by any human imagination. Considerations of technical usefulness played no role in Schlick's account nor did he take into account any relation between science and society. Instead, his account was motivated by mainly aesthetic or aestheticist considerations. His worldview was that of a theoretical physicist for whom mathematical and conceptual beauty was the most important criterion. ${ }^{24}$

As already mentioned, in the Vienna of the first decades of the past century there existed quite a few "Vienna Circles" in which philosophers, scientists, artists, politicians, and intellectuals met to discuss issues of common interest. One of the better known Vienna circles of this kind was the circle around Sigmund Freud that was the meeting point of people interested in matters psycho-analytical in a broad, not only technical sense. In 1932 the later Freud published the New Series of Introductory Lectures into Psychoanalysis. The last lecture of the New Series had the title On a Weltanschauung. It dealt with the question whether the new science of psychoanalysis could provide the basis for a comprehensive scientific worldview. Freud gave a well-considered and balanced response that deserves to be treated in some detail. First, Freud pointed out that "Weltanschauung" was a rather ambiguous and "difficult" word:

'Weltanschauung' is ... a specifically German notion, which it would be difficult to translate into a foreign language. ... By Weltanschauung, then, I mean an intellectual construction which gives a unified solution of the problems of our existence in virtue of which a comprehensive hypothesis, a construction, therefore, in which no question is left open and in which everything in which we are interested find a place. It is easy to see that the possession of such a Weltanschauung is one of the ideal wishes of mankind. When one believes in such a thing, one feels secure in life, one knows what one ought to strive after, and how one ought to organise one's emotions and interests to the best purpose. $^{25}$

Freud categorically denied that such a kind of Weltanschauung, which promises the solutions of all problems of humanity, would be compatible or consistent with psychoanalysis conceived as a science. Rather, psychoanalysis as a special science - was quite "unsuited to form a Weltanschauung of its own; it must accept that of science in general.". ${ }^{26}$ The scientific Weltanschauung is, however, markedly at variance with the "German definition" of Weltanschauung that he gave above. According to Freud, a truly scientific worldview could and should not make promises in a proper sense at all. It is characterized essentially in a negative and critical way by a limitation to what is, at any

\footnotetext{
${ }^{23}$ Schlick, 1934, p. 393.

${ }^{24}$ Schlick's high esteem of these factors is certainly due to the profound influence that Einstein's theories had had on him.

${ }^{25}$ Freud, 1933, p. 195.

${ }^{26}$ ibid.
} 
given time, knowable, and a categorical rejction of certain elements which are alien to it, namely, all kind of religious convictions. Freud's scientific worldview subscribed to a strict and comprehensive empiricism, it asserted that there was no other source of knowledge of the universe but the intellectual manipulation of carefully verified observations, no knowledge could be obtained from revelation, intuition, or inspiration of any kind.

Freud complained that, in contrast to earlier times, the 20th century had raised the objection that such a scientific Weltanschauung was both empty and unsatisfying, since it overlooked all the spiritual demands of man, and all the needs of the human mind. ${ }^{27}$ And he forcefully concluded: ""This objection cannot be too strongly repudiated." Indeed, Freud's version of a scientific worldview is one of the few that maintained a strong and explicit opposition against any kind of religious Weltanschauung. No other scientific worldview showed so radically anti-religious convictions as Freud's.

The case of Freud's version of a scientific world vision is particulary interesting because it was strongly marked by the results and methods of a "new" science, namely, psychoanalysis, and not, as is the case for most worldviews propounded by philosophers, by considerations of already firmly established natural science such as physics. Nevertheless, Freud explicitly admitted that psychoanalysis was not in a position to create a Weltanschauung of its own. It had no need to do so, for it is a branch of science, and can subscribe to the general scientific Weltanschauung. The latter, however, according to Freud, hardly merited such a high-sounding name, for it did not take everything into its scope, it was incomplete and made no claim to be comprehensive or to constitute a system. Scientific thought is still in its infancy; there are very many of the great problems with which it has as yet been unable to cope. A Weltanschauung based upon science has, apart from the emphasis it lays upon the real world, essentially negative characteristics, such as that it limited itself to truth and rejected illusions. According to Freud, a genuinely scientific attitude always emphasized the provisional and restricted character of scientific knowledge. These features, however, contradicted the global, allegedly all-explaining character of global worldviews.

The scientific worldviews of the Vienna Circle and Freudian psychoanalysis were not unrelated. The authors of the Manifesto tentatively considered the possibility that the psychological investigations of psychoanalysis might yield an explanation of the fact that so many people succumbed to the errors of metaphysics. In other words, the logical-empiricists hoped that psychoanalysis might provide methods for coping with metaphysical illnesses. At least some logical empiricists had explicit sympathies with the new science. For instance, as late as 1958 a symposiumPsychoanalysis. Scientific method and Philosophy - took place at New York University and it involved many former members, sympathisants, and students of the two circles, among them Philipp Frank, Ernest Nagel, Heinz Hartmann, Arthur Pap, Adolf Grünbaum. Frank, as president of the Institute for the Unity of Science, which may be considered as a successor organization of the Vienna Circle in the USA, came to a cautiously positive assessment of the scientific character of psychoanalysis:

[1]n terms of the general principles of Logical Positivism there is no reason for disliking psychoanalytical theories. It is a question to be determined by actual research, by observations and logical chains, whether theories such as Freud's should be approved by Logical Positivists. ${ }^{28}$

Others, like Ernest Nagel were less optimistic and considered the scientific status of psychoanalysis as still dubious. ${ }^{29}$ Heinz Hartmann, a former member of the Freud circle in Vienna and a logical empiricist, emphasized in his contribution Psychoanalysis as a scientific Theory that Freud always had aimed to ensure the scientific character of psychoanalysis, although he admitted that the master may have not always achieved it. ${ }^{30}$ To be sure, Freud's plea for a unified empiricist scientific worldview that took into account the achievements of psychoanalysis, does not entail, of course, that Freud himself and psychoanalysis actually followed the noble principles that the founding

\footnotetext{
${ }^{27}$ Freud, 1933, ibid.

${ }^{28}$ Frank, 1958, p. 313.

${ }^{29}$ cf. Nagel, 1958, p. 55.

${ }^{30} \mathrm{cf}$. Hartmann, 1959.
} 
master of this discipline porpounded in his lecture. Indeed, many analytic philosophers of science asserted that psychoanalysis had failed to be a science or that it was even a pseudoscience. ${ }^{31}$

\section{4 | THE WORLDVIEWS OF MORRIS' SCIENTIFIC EMPIRICISM AND CARNAP'S SCIENTIFIC HUMANISM}

Due to the political developments in Austria and Germany, namely the rise of National Socialism in Germany in 1933, and Clerical Austro-Fascism in Austria 1934, the Logical Empiricism and similar "scientific" philosophical currents began to disappear from the European scene by the middle of the 1930s at the latest: Most members of the Vienna Circle emigrated to the USA or England. As a result of this forced emigration, logical empiricism, originally a current of European philosophy, became an international philosophical movement. One of the protagonists of the internationalization of logical empiricism was the philosopher and semiotician Charles W. Morris. Sympathetic to the logical-empiricist philosophical project of the Vienna Circle, in the USA Morris became one of the most vocal advocates for the "Unity of Science Movement" as Logical empiricism became known there. In the 1930s and 1940s Morris closely collaborated with Neurath and Carnap as editor of the International Encyclopedia of Unified Science.

In this section l'd like to deal with two offsprings of the original Viennese scientific world conception, namely, Morris' "scientific empiricism" and Carnap's "scientific humanism." Morris's "scientific empiricism" may be characterized as the project of a synthesis of European logical empiricism and American pragmatism in the midst of the 1930s. For the first time it was presented to a wider philosophical audience at the First International Congress for the Unity of Science that took place in 1935 in Paris.

For Morris ${ }^{32}$ the encyclopedia project promised a new phase in the collaboration between philosophy and science. In this new phase, according to Morris, a new type of scholar appeared on the stage whom he characterized as a "logician scientist": This new type of scientist was neither content with the idle talk of traditional philosophical speculation nor did he accept the shallow repetition of logically not analysed concepts and assertions thus common in the sciences. Morris considered the program of the Unity of Science movement as the return of the venerable ideal of a global science that comprehended philosophy and empirical science in a new form. Thereby, at the end of the day, scientific philosophy and philosophical science would amount to the same. Both made the same global promise, namely, that it was possible to construct a rational, enlightened culture and society marked by the sciences. $^{33}$

Morris strongly emphasized that philosophy of science had to be a socially engaged philosophy of science. This entailed that philosophers had to get their hands "conceptually dirty." Dealing with issues concerning promises, risks, and threats of science often requires to rely on incomplete information, vaguely defined concepts, and sometimes doubtful argumentation. Philosophy had to get involved in these murky affairs, it could not always rely on "pure" concepts and live an isolated life "on the icy slopes of logic" as the Manifesto had expressed it. ${ }^{34}$ A "scientific philosopher" had to face the challenges of applied science. With this thesis of the unavoidability of "dirty concepts"

\footnotetext{
${ }^{31} \mathrm{cf}$. Grünbaum, 1984, Karl Popper, 1963. For a recent discussion of the various claims existing on the market concerning the scientific status of psychoanalysis, see The Freud Wars: Gomez, 2005, and the literature mentioned there.

${ }^{32}$ Jointly with Neurath and Carnap Morris was one of the editors the International Encyclopedia of Unified Science. This does not mean, of course, that the three editors always agreed on every detail of their philosophical outlooks. This not only held for the two logical empiricists Carnap and Neurath on one side, and the pragmatist Morris on the other, it also held, for instance, for Carnap and Neurath. For instance, over the last years of Neuraths life, he and Carnap had a bitter dispute on the issue whether semantics was acceptable for empiricists or not. Or, to give another example, the fact that Dewey published his pragmatist Theory of Valuation in the Encyclopedia can hardly be taken as evidence that Carnap endorsed whole-heartedly Dewey's pragmatist theory of values. For details of the vicissitudes of the Encyclopedia project see Reisch, 2005.

${ }^{33}$ cf. Morris, 1937, p. 3.

${ }^{34} \mathrm{cf}$. Neurath, 1929, p. 315.
} 
he agreed with Neurath, who had warned quite often his fellow empiricists of the Vienna Circle against overestimating the role of logical precision thereby succumbing to an unempiricist "pseudo-rationalism."

Morris' "scientific empiricism" clashed with the proposal that Carnap put forward in the programmatic paper Von der Erkenntnistheorie zur Wissenschaftslogik (From epistemology to logic of science), also presented at the Paris Congress of 1935. According to Carnap, one should neatly separate the logic of science and other disciplines occupied with psychological, sociological, or historical aspects of science. In opposition to Morris, Carnap described the recent progress of philosophy of science as a process of distillation through which step by step a "pure" logic of science had been distilled as the aseptic kernel of a scientific philosophy out of a metaphysically contaminated philosophy of the past:

The main phases of the development of scientific philosophy may perhaps be characterized as follows: First the task is to overcome metaphysics, i.e., the transition of speculative philosophy to epistemology. The second step was the overcoming of the synthetic a priori.... To me it seems that the aim of our present work consists in passing from epistemology to logic of science. Thereby epistemology is purified and dissolved into its elements. ${ }^{35}$

This "purification "of received philosophy of science led to a division of labor: The investigation of empirical facts is the task of empirical science, the task of investigating the linguistic forms of the language of science is the task of logical analysis. A third realm besides the empirical and the logical one is not admitted. Thereby philosophy of science falls into two parts, a genuinely philosophical one, namely the "logic of science," and in the rest, consisting of certain empirical disciplines such as history of science, psychology of science, or sociology of science about which Carnap had not much to say. According to Carnap, this program of the transition from epistemology to logic of science was actually no longer a program, but already a fact. The only thing still missing was to make this transition explicit in order to carry it out clearly and systematically. ${ }^{36}$

Obviously, Carnap's program is hard to reconcile with Morris's according to which there was no absolute break between theory and practice in science. Hence, there was no convincing reason why this should be different in scientific philosophy. He considered the exclusion of political, societal, and quite generally practically relevant aspects of science from philosophy of science proper as a sign of ethical irresponsibility:

It is important to distinguish dreams and fancies from expectations and proposals based on whatever data is available and controllable by new data obtained in use. It would be a signal instance of ethical irresponsibility to relinquish the demands which the need for a philosophically disciplined imagination imposes, and to turn the world over to the exclusive control of dreamers, adventurers, men of action, and technicians. ${ }^{37}$

Morris's program was in line with the proposals of other American pragmatists such as Clarence Irvine Lewis or Abraham Kaplan, who argued against making philosophy of science a discipline that exclusively dealt with the purely formal aspects of the scientific language. Lewis expressed the connection of knowledge, action, and valuation, essential for all varieties of pragmatisms, concisely as follows:

Knowledge, action, and evaluation are essentially connected. The primary and pervasive significance of knowledge lies in its guidance of action; knowing is for the sake of doing. And action, obviously, is rooted in evaluation. For a being which did not assign comparative values, deliberate action would be pointless; and for one which did not know, it would be impossible. Conversely, only an active

\footnotetext{
${ }^{35}$ Carnap, 1936, p. 37.

${ }^{36} \mathrm{cf}$. Carnap, 1936, p. 41.

${ }^{37}$ Morris, 1937, p. 20.
} 
being could have knowledge, and only such a being could assign values to anything beyond his own feelings. ${ }^{38}$

Lewis' thesis may be considered as the core thesis of the pragmatist's cognitivism concerning ethics that virtually all American pragmatists endorsed notwithstanding a few important differences. The logical empiricist Carnap never came close to it. At the end of the day, he remained a stubborn non-cognitivist. ${ }^{39,40}$ Carnap never openly disagreed with Morris's synthesis program. But he was not very enthusiastic about it. Instead of discussing in some detail Morris' critical remarks on the differences between Logical empiricism and pragmatism, in his Intellectual Autobiography (1963), in his reply to Morris Carnap attempted to pass over these differences with the following bland assertion:

I am inclined to agree with Morris that the difference between my view and that of the pragmatists is not as large as it might appear at first glance. ${ }^{41,42}$

With respect to the worldview of the Vienna circle in the 1920s and early 1930s Carnap was content to describe it in general terms as "scientific humanism" that he characterized by the following five theses ${ }^{43,44}$ :

1. Man has no supernatural protectors or enemies and therefore what can be done to improve life is the task of man himself.

2. Mankind is able to change the conditions of life in such a way that many of the sufferings of today may be avoided and the external and the internal situation of life for the individual, the community, and finally for humanity will be essentially improved.

3. All deliberate action presupposes knowledge of the world, the scientific method is the best method of acquiring knowledge and therefore science must be regarded as one of the most valuable instruments for the improvement of life. ${ }^{45}$

4. The great problems of the organization of economy and the organization of the world at the present time, in the era of industrialization, cannot be solved by "the free interplay of forces," but require rational planning. For the organization of economy this means socialism in some form; for the organization of the world it means a gradual development toward a world government.

5. Socialism and world government, according to our present knowledge, give the best promise of a realization of the ultimate aim that is a form of life in which the well-being and the development of the individual is valued most highly, not the power of the state. ${ }^{46}$

\footnotetext{
${ }^{38}$ Lewis, 1946, An Analysis of Knowledge and Valuation, 5.

${ }^{39}$ cf. Carnap, 1963.

${ }^{40}$ This does not mean that Carnap's non-cognitivist stance concerning ethics was shared by all logical empiricists of the Vienna Circle. For a detailed discussion of the the variety of views taken by the members of the Vienna Circle, see Siegetsleitner, $2010,2014$. ${ }^{41}$ Carnap, 1963, p. 862.

${ }^{42}$ How to describe the changing relations between American pragmatism and logical empiricism in the middle of the past century is a contentious issue in history of philosophy. According to the "received view" pragmatism had been simply replaced by logical empiricism when the latter arrived in the New world. Recent scholarship denies this story as oversimplified. Taking into account important similarities and intense interactions between the two schools in the 1930s and 1940s many philosophers have come to describe the relation between them as a sort of "convergence." Others insisted that important differences remained. For details the reader should consult the literature, see Richardson, 2003, 2007; Mormann, 2007, 2017; Misak, 2013. Probably, in order to be able to obtain more specific assessments concerning the issue of pragmatic versus logical empiricist aspects, it would be expedient to consider the philosophical evolution of individual philosophers.

${ }^{43}$ Carnap, 1963, p. 83.

${ }^{44}$ Traces of this worldview may be found already in Carnap's early (non-published) manuscript Deutschlands Niederlage - sinnloses Schicksal oder Schuld? Carnap, 1918. For a discussion of early Carnap's worldview in the context of the German Youth Movement, see Mormann, 201X (Unpublished Manuscript).

${ }^{45}$ Carnap, 1963, p. 83.

${ }^{46}$ ibid.
} 
The principles (1)-(3) are general principles of a rational secular worldview, which, outside an an anti-scientific and theologically infected camp, are hardly in danger of being critizised. Things are different, of course, with theses (4) and (5). They are rather controversial, but nevertheless they have never been seriously discussed by Carnap himself nor Carnap scholars.

However one may assess Morris's and Carnap's theses, one may safely assert that in the 1950s and 1960s their influence on the then contemporary philosophy of science was marginal. In the second half of the 20th century the perspective of a socially engaged philosophy of science began to look rather bleak. The issue of global scientific promises, to say nothing about global scientific Worldviews disappeared from the agenda of mainstream analytic philosophy of science. During the 1950s philosophy of science showed an increasing tendency to declare their approach "neutral" with respect to all political and ideological differences. "Scientific" philosophy became more and more opposed to "committed" or "engaged" philosophy. Commitment became the mark of existentialists, marxists, maoists, and critical theorists, later to be complemented by ecologists and feminists. Without detracting from the merits of those movements for a politically committed criticism of science, one may note that they did not fill the gap created by the disappearance of an articulated, critical empirical philosophy of science as an institution being capable of assessing rationally the reasonableness and feasibility of the various global promises put forward by authorized and unauthorized people in the name of science.

\section{5 | CONCLUDING REMARKS}

Compared with the received philosophy of science of late 20th century, at the start of the 21st centry there are signs that the tides have changed again. Since 2000 , a socially engaged philosophy of science that takes seriously the study of the relationship of science and society steadily gains momentum. A survey of the more recent activities in this direction may be found in Cartieri and Potochnik's paper "Toward Philosophy of Science's Social Engagement". ${ }^{47}$ In this paper a wealth of actitivies and newly founded institutions engaged in this area are listed, among them the formation of a Society of Socially Engaged Philosophy of Science (SEPOS). From the perspective of this "socially engaged philosophy of science" the abstract epistemological Kantian question of philosophy of science, namely, "What can we know?" should be replaced by a more "subjective" one, namely:

What is it that we want to know?

This is no longer a scientific question in the traditional narrow sense that can be answered by science alone. Rather, an answer to this question requires a wise coordination and interaction of social and scientific values. This is an endeavor that can hardly be expected to be carried out by scientists alone. Philosophers of science are called for. Cartieri and Potochnik are quite optimistic concerning the role that philosophers of science could play in this project:

The productive coordination of scientific and social values should not be shouldered by scientists alone, as they are not particularly qualified for this task.

In contrast, the training of philosophers of science is particularly useful in this connection. Philosophy of science offers a rich field of perspectives wide enough to capture the complexity of relations between science and society and critical enough to assess the underlying assumptions, interests, and histories of socio-scientific conflicts - and even to help resolve such conflicts. The skillset of philosophers of science, collectively, includes a special "toolkit" of method and understanding. Methodologically, philosophers of science are trained in the use of critical analysis, skepticism, and dialogue as a means to generate understanding. ${ }^{48}$

\footnotetext{
${ }^{47}$ Cartieri and Potochnik, 2014.

${ }^{48}$ Cartieri and Potochnik, 2014, p. 906.
} 
Whether philosophy of science can actually satisfy these high expectations, remains to be seen. In any case, the changing fortunes of global scientific promises in the course of history of philosophy of science suggest that philosophers, who deal with the problem of promises in science, should adopt a perspective that also takes into account the history of this issue. This might serve as an antidote against the naive idea that the history of philosophy of science has been a history of permanent and unilateral progress in the sense that today we obviously possess a better philosophical understanding of the sciences than our forefathers. Rather, the more progress history of philosophy of science made in recent years the more it became clear how much remains to be done for achieving an adequate understanding of the still young discipline called philosophy of science. Thereby we may refute Adorno's dictum according to which the history of philosophy is the history of forgetting. At least to some extent, SEPOS avoids this shortcoming by acknowledging that already the Vienna Circle's account of philosophy of science (as expressed in the Scientific World-Conception)

has clear social dimensions. It is focally concerned with improving human welfare ... Carnap, Hahn, and Neurath held a view of philosophy of science according to which the discpline plays a 'superstructural' role in society that has significant social and political components. Philosophers are tasked with articulating and advocating these connections, as scientists themselves must focus their energies elsewhere. ${ }^{49}$

The Manifesto, however, was only one among quite a few other worldviews concerned with science. SEPOS does not mention any other socially engaged worldview except the Viennese one. ${ }^{50}$ This is surprising insofar, as the social engagement of American pragmatism arguably was at least as eye-catching as that of Logical empiricism. ${ }^{51}$

This is not to suggest that pragmatism is generally to be preferred over logical empiricism if social engagement of philosophy of science is at stake. Rather, l'd like to argue that contemporary socially engaged philosophy of science should take into account a larger section of the spectrum of the various scientific worldviews of the past. This may perhaps enable us to more consciously avoid possible blindspots and weak points of competing perspectives. For instance, the obsession of certain logical empiricists against any kind of alleged metaphysics or the habit of others to concentrate on subtle technical details of matters logical certainly did not help make more visible their social engagement to a wider public. In this respect, the American pragmatism of Dewey, Lewis, and James is much more congenial to a socially engaged philosophy of science than, say, the austere logical empiricism of Carnap. This remark does not intend to play off logical empiricism against pragmatism. Rather, it suggests the need for a closer look at the rich legacy of socially engaged philosophies than just mentioning the high-sounding proclamations of the Manifesto. For instance, it would certainly be worth the effort to take into account Morris' rather forgotten "scientific empiricism" ${ }^{52}$ or what may be called the Austro-American Logical Empiricism of Philipp Frank. ${ }^{53}$ In other words, when the Manifesto is rightly considered as useful to help us imagine what a socially engaged philosophy of science may look like there are good reasons also to take into account the other "manifestos": Something may be learned from them as well, perhaps even when they choose a path that differed from that of the logical empiricists of the Vienna Circle.

\section{ORCID}

\section{Thomas Mormann (D) http://orcid.org/0000-0002-7727-0610}

\footnotetext{
${ }^{49}$ Cartieri and Potochnik, 2014, p. 903.

${ }^{50}$ This does not only hold for SEPOS as characterized by Cartieri and Potochnik, it seems to hold quite generally for the new "engaged" philosophy of science. For instance, in the "manifesto" for a "socially relevant philosophy of science" (SRPOS) of Fehr and Plaisance, 2010 no reference of any historical precursors is mentioned.

${ }^{51}$ Moreover, as is well known that in the US Logical Empiricism lost a lot of its social impetus that it had had in Europe, cf. Reisch, 2005. Thus, the Manifesto can hardly be considered as a characteristic statement of an American Logical Empiricism.

${ }^{52}$ Morris, 1937.

${ }^{53}$ cf. Frank 1949, Reisch, 2005, Mormann, 2017.
} 


\section{REFERENCES}

Carnap, R. (1918). Deutschlands Niederlage - Sinnloses Schicksal oder Schuld?, Unpublished Manuscript (RC - 089 - 72 - 04$)$, Archives of Scientific Philosophy, Carnap papers (ASP). Hillman Library, University of Pittsburgh.

Carnap, R. (1936). Von der Erkenntnistheorie zur Wissenschaftslogik, In Actes du Congrès international de philosophie scientifique, Actualitès scientifiques et industrielles 388. Paris, France: Hermann.

Carnap, R. (1963). Intellectual autobiography. In P. A. Schilpp (Ed.), The philosophy of Rudolf Carnap (pp. 3-84). LaSalle, IL: Open Court.

Cartieri, F., \& Potochnik, A. (2014). Toward philosophy of science's social engagement. Erkenntnis, 79(3), 901-916.

Fehr, C., \& Plaisance, K. S. (2010). Socially relevant philosophy of science - an introduction. Synthese, 177, $301-316$.

Frank, P. (1958). Psychoanalysis and logical positivism. In S. Hook (Ed.), Psychoanalysis, scientific method and philosophy (pp. 308-313). New York, NY: Grove Press.

Freud, S. (1933). The question of a Weltanschauung. In New introductory lectures on psychoanalysis (The Standard Edition, Complete Psychological Works of Sigmund Freud) (pp. 195-226). New York, NY: Norton.

Gomez, L. (2005). The Freud wars. An introduction to the philosophy of psychoanalysis. New York, NY: Routledge.

Grünbaum, A. (1984). The foundations of psychoanalysis: A philosophical critique. Berkeley, CA: University of California Press.

Hartmann, H. (1959). Psychoanalysis as a scientific theory. In S. Hook (Ed.), Psychoanalysis, scientific method and philosophy (pp. 3-37).

Lewis, C. I. (1946). An analysis of konwledge and valuation. LaSalle, IL: Open Court.

Misak, C. (2013). The American pragmatists. Oxford, England: Oxford University Press.

Mormann, T. (2007). Carnap's logical empiricism, values, and American pragmatism. Journal for General Philosophy of Science, 38, 127-146.

Mormann, T. (2017). Philipp Frank's Austro-American logical empiricism. HOPOS, 7(1).

Morris, C. W. (1937). Logical positivism, pragmatism and scientific empiricism, Exposés de Philosophie Scientifique 449. Paris, France: Hermann.

Nagel, E. (1958). Methodological issues in psycholanalytic theory. In S. Hook (Ed.), Psychoanalysis. Scientific Method and Philosophy (pp. 38-56). New York, NY: Grove Press.

Neurath, O. [1929] (1981). Wissenschaftliche Weltauffassung. Der Wiener Kreis. In O. Neurath (Ed.), Gesammelte philosophische und methodologische Schriften Band 1 (pp. 299-366). Wien, Austria: Hölder - Pichler-Tempsky.

Popper, K. (1963). Conjectures and refutations. London, England: Routledge.

Reisch, G. A. (2005). How the cold war transformed philosophy of science. To the icy slopes of logic. Cambridge, England: Cambridge University Press.

Richardson, A. W. (2003). Logical empiricism, American pragmatism, and the fate of scientific philosophy in North America. In G. L. Hardcastle \& A. W. Richardson (Eds.), Minnesota studies in philosophy of science (pp. 1-24). London, England: Oxford University Press.

Richardson, A. W. (2007). Carnapian pragmatism. In M. Friedman \& R. Creath (Eds.), The Cambridge companion to Carnap (pp. 295-315).

Romizi, D. (2012). The Vienna Circle's "scientific world-conception": Philosophy of science in the political arena. HOPOS, 2 (1), 205-242.

Romizi, D. (2013). War die "wissenschaftliche Weltauffassung" des Wiener Kreises nicht doch auch eine Weltanschauung? Veröffentlichungen des Instituts Wiener Kreis, 18, 127-151.

Schlick, M. (1930). Die Wende in der Philosophie. Erkenntnis, 1, 4-11.

Schlick, M. (1934). Philosophie und Naturwissenschaft. Erkenntnis, 4, 379-396.

Siegetsleitner, A. (2010). Logischer Empirismus, Werte und Moral. In E. Neubewertung (Hrg.), Veröffentlichungen des Instituts Wiener Kreis, Bd. 15. Wien, Austria: Springer.

Siegetsleitner, A. (2014). Ethik im Wiener Kreis. Zur Geschichte eines engagierten Humanismus. Böhlau Verlag: Wien, Austria.

Timms, E. (1996). Die Wiener Kreise. Schöpferische Interaktionen in der Wiener Moderne. In J. Nautz \& R. Vahrenkamp (Hrsg.), Die Wiener Jahrhundertwende. Einflüsse, Umwelt, Wirkungen (pp. 128-143). Wien, Graz, Austria, Köln, Germany: Böhlau.

Uebel, T. (2012). On the production history and early reception of the scientific conception of the world. The Vienna circle. In F. Stadler \& T. Uebel (Eds.), Wissenschaftliche Weltauffassung. Der wiener Kreis. Herausgegeben vom Verein Ernst Mach. (1929), Reprint of the first edition, on behalf of the Institute Vienna Circle on the occasion of its 20th anniversary, 2012. With translations into English, French, Spanish and Italian, (pp. 291-314). Wien, Austria and New York, NY: Springer.

How to cite this article: Mormann T. Scientific worldviews as promises of science and problems of philosophy of science. Centaurus. 2017;59:189-203. https://doi.org/10.1111/1600-0498.12159 